DOI: http://doi.org/10.22364/ruslat.glp.15

Татьяна Савчук

\title{
Семантико-прагматические ошибки в научной аргументации (на материале русских и белорусских гуманитарных текстов)
}

В статье преАставлен результат могико-лингвистического анализа русско- и беморусскоязычного научно-гуманитарного Аискурса. Систематизируются семантико-прагматические ошибки, источником которых явцяется неадекватное использование языковых среАств вслеАствие нарушения принципа интерпретируемости. Характеризуются такие виды девиаций, как семантическая деформация, категориальный сАвиг, семантический сбой, референциальная неопределенность, семантико-прагматический Аиссонанс и Ар. Описываются механизмы возникновения этих погрешностей, обосновывается их семантико-прагматическая природа.

Ключевые слова: аргументация, аргументативная ошибка, научно-гуманитарный Аискурс, русский язык, беморусский язык

\section{Введение}

Исследование аргументации - особой интемлектуально-коммуникативной Аеятельности, связанной с прагматикой убежАения, - преАполагает не только описание аргументативного Аискурса, но также его критический анализ и оценку. Критический подход к аргументирующему рассужАению предусматривает установление критериев его правильности и созАание типологии ошибок. Как отмечают аргументологи, разработка «адекватных ПоАходов к определению разАичных виАов ошибок и соответствующих методов их идентификации в реацьных аргументативных практиках» явцяется приоритетным направлением современной теории аргументации (van Eemeren et al. 2014: 25).

Опыт изучения аргументации в нормативном аспекте имеет давнюю традицию, восходящую к трудам Аристотемя, таким как «Топика», «Риторика», «О софистических опровержениях $\gg^{1}$. Вместе с тем универсальная и общепризнанная теория аргументативных ошибок Ао сих пор не созАана. Объясняется это, прежАе всего, размичием исслеАовательских подходов к Аанной проблеме. Кроме того, Аискурсивные практики настолько многообразны и специфичны, что стандарты их критического измерения еАва $\Lambda и$

1 Ретроспективный обзор теоретических подходов к нормативному исследованию аргументации см. в: (van Eemeren 2001: 135-164). 
поААаются унификации. В этой связи особую важность приобретает созАание нормативных концепций, ориентированных на определенные типы Аискурса.

Объектом нашего исследовательского интереса явмяется аргументация в Аискурсе гуманитарных наук. Согласно авторской концепции, критический анализ научно-гуманитарного Аискурса производится на трех уровнях рациональности: структурном, вербально-семантическом и стратегическом. В фокусе Аанной статьи находится языковой уровень аргументирования. В работе ставилась цель эксплицировать нормы вербального преАставления аргументации, систематизировать ошибки, допускаемые в аргументирующем рассуждении. Анализ проводился на материале научных статей по различным направлениям гуманитаристики (социологии, психологии, культурологии, мингвистике, журналистике), опубликованных в рецензируемых журналах за 2001-2015 гг. Фактологическая база включает 300 научных текстов: 150 на русском языке и 150 на белорусском языке. Основным методом исследования стал могико-лингвистический анализ; были использованы также Аискурс-анализ и метод интерпретации.

Наша нормативная модель строится с учетом общезначимых характеристик аргументации (см., напр., Брутян 1992: 9-24), а также специфических свойств письменного научно-гуманитарного дискурса, таких как высокий уровень рациональности, ответственности и аргументативной компетентности участников, цемевая установка на кооперативное взаимодействие, преАварительная продуманность и подготовменность коммуникации.

Опорой А^я нашей теории послужили: известный Принцип кооперации Г.П. Грайса (Grice 1975: 41-58); общий Принцип коммуникации, разработанный Ф.Х. ван Еемереном и Р. Гроотендорстом: «Будь ясным, честным, эффективным и точным» (ван Еемерен, Гроотендорст 1992: 50-57); сформулированные Аж. Аичем Принципы текстопостроения: перерабатываемости, ясности, экономии, выразительности (Leech 1983: 63-70), а также признанные в общей теории коммуникации, теории речевого возАействия и аргументологии конвенции и правила общения (Аемьянков 1982: 327-337). Кроме того, мы учитывали результаты наблюАений и выводы, сАеланные мингвистами в рамках «ортологии научной речи» (см., напр.: Киримлова 2015; Матвеева 2000; Чернявская 2011)².

2 Заметим, что попытка языковедческой разработки критериев нормативности затрагивает преимущественно один аспект - метатекстовую коммуникацию. В целом же исследование проблемы нормативной организации научной речи в рамках стилистики и текстолингвистики сводится К описанию языковых (коммуникативных) фактов, касающихся смысловых и структурнокомпозиционных характеристик разных видов научной прозы (см., напр., работы Е.А. Баженовой, М.Н. Кожиной, М.П. Котюровой, Н.К. Рябцевой). 


\section{Нормы вербального представления аргументативных структур в научно-гуманитарном дискурсе}

В качестве базового принципа, с которым следует согласовывать языковое оформление научно-гуманитарной аргументации, нами выдвигается принцип интерпретируемости ${ }^{3}$ вербальная репрезентация аргументативных структур Аолжна быть такой, чтобы реципиент смог адекватно их идентифицировать, понять, истолковать и реконструировать.

Из принципа интерпретируемости следуют Ава правила: 1) правило смысловой точности и 2) правило наАлежащего употребления аргументативных вербализаторов. Результатом нарушения правиц становятся аргументативные ошибки - неверные, неадекватные аргументативные действия, препятствующие реализации прагматики убеждения.

1. Правимо семантической точности: словесные формулировки в аргументирующем рассужАении Аолжны быть четкими и (по возможности) однозначными. Оптимальное формулирование суждений, максимально точное выражение мыслей - необходимые условия понимания сообщения и во многом залог успешной аргументации ${ }^{4}$. Смысловые погрешности в аргументации, возникающие в результате отклонения от этого правила, имеют прагматическую природу: они препятствуют Аостижению перлокутивного (убежАающего) эффекта 5 .

Зафиксированы следующие разновидности семантико-прагматических Аевиаций.

Семантическая Аеформация - искажение сигнификата вербальной еАиницы вслеАствие употребления ее в несвойственном ей значении. Аеформации подвергается смысл таких частотных Аля научного обихода понятий, как парадигма, коммуникация, таксономия, понятие, термин, концепт, аргументация (причем чаще смысловые искажения допускают русскоязычные авторы). Но больше всего (и в русском, и в белорусском Аискурсах) зафиксировано случаев Аеформированного употребления слова дефиниция: «Нет четких терминологических подходов к самой Аефиниции "политическая система” $\gg\left(\right.$ CA3: 44) ${ }^{6}$; «...считаем целесообразным свести названные выше “множественности” с частицами “мже”, “псевдо”, “квази”, “Аеви”

3 Под принципом здесь понимается конвенциональное фоновое требование к коммуникации.

4 Следует заметить, что традиционно в мингвистическом науковедении понятийная точность рассматривается как «доминанта научного стимя» (см. Кириммова 2015: 69).

5 Обратим внимание, что погрешности, связанные с нарушением требования смысловой точности, явмяются инвариантым элементом практически всех известных классификаций аргументативных ошибок, от античных до современных; это траАиционно находит отражение в учебной митературе по могике и риторике.

6 При ссылках на источники фактического материала здесь и Аалее используются усмовные обозначения (см. Список источников примеров в конце статьи). 
к оАной Аефиниции: “паранаука” или вообще отказаться от него, заменив жесткую и “режущую слух” Аефиницию “паранаука” ... термином “Аругое знание” » (НИК1: 96); «Першапачаткова Аэфініцыя метанімія ўмяшчала ў свой змест моўнае і мітаратуразнаучае тмумачэнне аднаго з тропаў...» (Первоначально дефиниция метонимия вмещала в свое содержание языковое и митературовеАческое объяснение одного из тропов...) (ВБАУ1: 74); «"ВяАучая тэнАэнцыя” - гэта Аэфініцыя, якая ўключае ў сябе і ўмовы фарміравання азначанай асобаснай уласцівасці, і саму ўласцівасць...» («ВеАущая тенАенция - это Аефиниция, которая включает в себя и условия формирования указанного мичностного свойства, и само свойство... ) (ВБАПУЗ: 33).

В приведенных примерах наблюдается смешение смыслов ментальных еАиниц, обозначаемых номинациями дефиниция, термин, понятие. Этот факт вызывает удивление: веАь значения этих слов фиксируются в мексикографических изАаниях. В частности, по Ожегову, дефинииия - 'опредемение, истолкование понятия' (Ожегов 1990: 166); согласно философским словарям и учебникам могики, поА Аефиницией понимается могическая операция, раскрывающая содержание имени посреАством описания существенных признаков предметов, обозначаемых данным именем (см., напр.: Савчук 2003: 20).

Категориахьный сАвиг - объеАинение, сопоставление понятий, относящихся к разнопорядковым категориям. Больше примеров такой погрешности зафиксировано в текстах на русском языке: «В науке есть четкое разграничение этих понятий, в телевизионном тексте это сАелать сложнее...» (НПЖ2: 63); «КАючевое терминопонятие “культурно-речевая компетенция” имеет интегральный (родовой) статус по отношению к состав яющим его основным (базовым) компетенциям» $(\Phi \mathrm{H} 2: 3)$.

Некорректное соотношение понятий отмечается и в белорусскоязычных текстах: «...ў сучасных умовах светапоглядныя ўстаноўкі функцыянуюць не на тэарэтычным узроўні, а на ўзроўні сегментарным, выбарачным i, хутчэй за ўсё, паўсялзённым» (...в современных условиях мировоззренческие установки функционируют не на теоретическом уровне, а на уровне сегментарном, выборочном и, скорее всего, повсеАневном) (ВНАНБ3: 13).

Семантический сбой - алогизм, возникающий в результате подмены понятий и, как слеАствие, неоправАанного смещения преАмета рассужАения в сторону смежной категории. Такая ошибка - частое явление в гуманитарном Аискурсе: «Аиалог, коммуникация - это, несомненно, и Аискуссия, и обсужАение, и взаимоАействие АюАей и иАей ... Ни ОАно из этих наименований не выглядит панацеей от всех беА...» (СА6: 34) - в Аействительности речь идет не о наименованиях, а о понятиях, обозначаемых ими; «Аанное сужАение является кАючевой проблемой всего белорусского спорта, когда перспективный спортсмен в юном возрасте показывает выдающиеся результаты, а при переходе во взрослый спорт не может себя проявить» (СА4: 474) - проблемой, вероятно, явмяется отраженная в сужАении ситуация; «Існуюць асаблівыя жыщщёвыя сітуацыі, якія нельга вырашыць 
працэсамі прадметна-практычнай і пазнавальнай Азейнасці. ААнак іх вырашаюць працэсы перажывання» (Существуют особые жизненные ситуации, которые нельзя решить процессами предметно-практической и познавательной Аеятельности. ОАнако их решают процессы переживания) (ВБАПУ4: 46) - проблемные ситуации можно решить, скорее, не процессами, а Аействиями; «Узаемадзеянне паняццяў культура - дзяржава і дзяржава - культура абумоўлена ix узаемнай патрэбай. Гэта патрэба вызначае ў канчатковым выніку ўсе разнастайныя формы іх кантактаў, накіраванасць і глыбіню ўзаемаўплыву» (Взаимодействие понятий культура - государство и государство - культура обусловлено их взаимной потребностью. Эта потребность определяет в конечном итоге все разнообразные формы их контактов, направценность и глубину взаимовлияния) (ВНАНБ4: 74) - корректно бымо бы говорить о взаимодействии не понятий, а предметов, мыслимых в этих понятиях.

Авусмысленность - использование выражений, Аопускающих неоднозначную трактовку. В некоторых случаях смысл высказывания уточняется послеАующим контекстом: «НереАко поА влиянием обстоятельств или вспыльчивости молодые мюАи совершают поступки, которые в Аальнейшем негативно влияют на жизнь и карьеру. Особую опасность Аля молодых мюАей преАставляет социальное окружение: Арузья, товарищи по школе, сосеАи, знакомые и Ар. Согласно Аанным социологического исследования Института социологии НАН РБ (октябрь 2010 г.), 65,1\% респонАентов имеют знакомых, которые змоупотребцяют спиртными напитками» (CA5: 419).

В Аругих ситуациях Авусмысленность не устраняется контекстуально: «Производство и самореализация творческих мюАей опреАеляют новые походы к потреблению. Потребители престижных бцаг оказывают влияние на качество и стиль жизни инАивиАов, тем самым способствуют укреплению социальной системы...» (СА2: 255); «...калі атрымліваецца незразумелы аАказ, чамавек аАразу шукае імпмікатуру і звычайна яе знаходзіць нават у самых нечаканых месцах. Гэта і становіцца агульнай часткай пытання i алказу, якія ў нашым выпадку і ўяўяюць сцэнарную апазіцыю» (...если получается непонятный ответ, человек сразу ищет импликатуру и обычно ее находит даже в самых неожиданных местах. Это и становится общей частью вопроса и ответа, которые в нашем случае и представляют сценарную оппозицию) (БА: 141).

Референциальная неопределенность - частный случай Авусмысленности - возникает в результате неадекватного употребления разного рода Аейктических среАств: «АюАи разговаривают межАу собой Аискурсами, а не предложениями и тем более не морфемами или фонемами. Это отличает Аискурс от Аругих языковых еАиниц, которые преАставмяют собой научные конструкты, плоды того или иного анациза...» (ВЯ: 3) - вслеАствие непроАуманного использования указательного местоимения остается неясным, какое именно свойство приписывается преАмету мысли - Аискурсу; «Асэнсаванне сябе ў сям’ і хаця і не поўнасцю ўсведамляецца Азіцем, але яно вызначае яго рэакцыі на тое, што адбываецца» (Осмысление себя в семье хотя и не 
полностью осознается ребенком, но оно определяет его реакции на происходящее) (ВБПАУ 1: 42) - причина Авусмысленности - неАифференцированное употребление местоимений 3-го мица.

Искажение реальных могических связей вслеАствие неалекватного синтаксического и пунктуационного оформиения рассуждения. Пример такой ошибки обнаружен в русскоязычном речевом материале: «Язык при всей своей системности от незаполненности ряда макун вовсе не страАает. А возникновение красного словца (Аогоэпистемы) никакой необхоАимостью не мотивировано. Сказал (написал). Услышами (прочитали). Понравияось (повторияи). Вот могоэпистема и возникца» (ФН1: 8). Аогика и прагматика вылеленной фразы проясняется только в результате корректировки ее синтаксиса и пунктуации: Сказал (написал) - усльщшали (прочитали). Понравилось - повторили.

Крайним проявмением семантико-прагматической Аевиантности явмяются рассужАения и тексты, которые не подАаются пониманию и реконструкции, а потому квалифицируются как неинтерпретируемые. В них слова и смысл существуют парамлельно, мибо смысл скрыт настолько глубоко, что Аля его Аешифровки могических и мингвистических знаний недостаточно:

«Совершенствование форм народной хоровой практики взаимосвязано с общеметодологическими основами, расширяющими её Аейственность от художественно-эстетических рамок Ао социокультурного инструментария, средства объединения мюдей, их самосовершенствования на основе богатства национального культурного наслеАия (НИК2: 42); «При невысоком количестве антропонимических еАиниц и суженности круга смысловых векторов многократность употребления этих онимов в текстовом пространстве составмяет 455 раз. <...> ОАнако анациз показывает, что значительное увеличение фреквентативных показателей послеАнего критерия максимально наполняет прагматическим смыслом антропонимные единицы в обозначенных социально-индикационных направлениях и мокализует Аействующих миц в зоне героев второго плана автора-повествователя» (ВБАУ3: 72).

Эти текстовые фрагменты Аемонстрируют явление, названное Г.Г. Хазагеровым «Аисфункцией научного Аискурса». Оно обусловлено «рассогласованностью прагматических установок: самопрезентацией ученого и презентацией новых научных идей» (Хазагеров 2010: 5). Причем одним из наиболее ярких признаков такой Аисфункции, по мнению исследователя, служит «змоупотребление модными научными идиомами» (Хазагеров 2010: 17), что и наблюдается в приведенных выше русскоязычных рассужАениях.

Примеры неинтерпретируемых речевых построений отмечены и в белорусском Аискурсе: «Мэта нашага эмпірычнага Ааследавання - вызначэнне спецыфікі ўспрымання рэкламнага паведамлення студэнтамі сродкамі выяўлення катэгарыяльнай структуры ўспрымання Арукаванай рэкламы, якая 
ўтрыммівае або жаночы, або мужчынскі вобраз» (Цель нашего эмпирического исследования - определение специфики восприятия рекламного сообщения студентами средствами обнаружения категориальной структуры восприятия печатной рекламы, которая содержит ими женский, или мужской образ) (ВБАПУ2: 59); «У цэлым жа за кошт значнага перавышэння памераў памяншэння колькасці кандыдатаў навук наА павелічэннем колькасці дактароў у аналізуемых аб'ектах сістэмы органаў дзяржаўнага кіравання адбылося памяншэнне колькасці даследчыкаў вышэйшай кваліфікацыі - на 1,9\%» (В целом же за счет значительного превышения размеров уменьшения комичества кандидатов наук наА увеличением количества врачей в анализируемых объектах системы органов госуАарственного управления произошло уменьшение количества исследователей высшей квалификации - на 1,9\%) (ВНАНБ2: 11).

В оценке таких текстов сошлемся на мнение специалистов-ортологов: «Аелает научную речь плохой всё, что мешает ее адекватному пониманию, в том числе... стремление к наукообразию в ущерб научности...» (Кирилмова 2015: 84). 3Аесь кажется уместным вспомнить известный афоризм: Кто ясно мыслит - ясно излагает!

2. Правимо компетентного употребления аргументативных вербализаторов: используемые в обосновании языковые индикаторы аргументации должны коррелировать с теми видами аргументативных связей, структур, отношений, которые они обозначают. В противном случае возникает ошибка, которую мы назвали можной навигацией. Суть ее в том, что семантика объективирующих аргументацию языковых среАств не соответствует их прагматической роли. Это приводит к дезориентации воспринимающего субъекта, который «направмяется по Аожному пути».

Охарактеризуем Ава, наиболее распространенных, вида можной навигации.

Употребление фиктивных вербализаторов - использование маркеров аргументации при фактическом отсутствии репрезентируемых ими значений. Особенно часто такая ошибка возникает при употреблении аргументативных кмише, преАназначенных дмя выражения тезиса: рус. таким образом; следовательно; из этого следует/вытекает; мы убедились в том, ито; можно утверждать/сделать вывод, что; ввиду этого; бел. такім чынам; з гэтага вынікае, ито; таму можна зрабіиь вывад, ито; гэта дае падставы сивлрджаць/гаварыць и т.п. Подобные вербализаторы далеко не всегда выполняют свою функцию в Аискурсе. Используясь фиктивно, они выступают как «"Аожные Арузья” интерпретатора»: скрывают могическую ошибку «не следует», которая свидетельствует о несостоятельности аргументации (см.: Савчук 2016: 467).

Употребление псевдовербализаторов зафиксировано и в русско-, и в беморусскоязычной гуманитаристике.

«Так как промышленное производство не акцентируется на преАметах роскоши, нет необходимости в накопмении денег на роскошные товары. 
Таким образом, необходимым условием развития общества является распространение инноваций. Возникновение новых производственных отраслей расширяет слой потребителей. Из этого следует, что с развитием инновационных технологий новые предметы потребления становятся Аоступными в зависимости от потребительских преАпочтений высшего класса. Таким образом, инновационный продукт взаимосвязан с различием бедных и богатых слоев насемения» (СА1: 254). Этот пример примечателен тем, что ни один из включенных в обоснование вербализаторов не реализует свое прагматическое значение.

«Такім чынам, на наш погляА, тэлешоу валодае Аастатковай колькасцю фармальных і змястоўных прымет, якія аАрозніваюць яго аА іншых сённяшніх тэлепрадуктаў, каб выкучыць яго ў якасці асобнага жанру сучаснай тэлежурналістыкі. ПаАагульняючы ўсё сказанае, зробім выснову: тэлешоу гэта праграма, якая характарызуецца пастановачнасцю і відовішчнасцю, наяўнасцю вялікай колькасці камунікатыўных ромяў, асноўная мэта якой забаўленне аўдыторыі або інфармаванне і асвета праз сродкі забаўляльнага тэлевяшчання» (Таким образом, на наш взгляА, телешоу облаАает достаточным количеством формальных и содержательных признаков, которые отличают его от Аругих сегодняшних телепродуктов, чтобы выдемить его в качестве отдельного жанра современной тележурналистики. Подытоживая все сказанное, сделаем вывоА: телешоу - это программа, которая характеризуется постановочностью и зрелищностью, наличием большого количества коммуникативных ролей, основная цель которой - развлечение аудитории или информирование и просвещение через среАства развлекательного темевещания) (ВБАУ2: 85). Насыщенность текста аргументативными клише Аает все основания реципиенту квамифицировать маркируемые ими высказывания как главный тезис аргументации (Телешоу - это особый жанр современной журналистики, который обладает специфическими свойствами). ОАнако Аискурсивный анализ показывает, что такая интерпретация неправомерна: приведенный фрагмент находится в середине текста и восстановленный тезис не имеет прямой корреляции с заголовком («Шоу ў сістэме тәлевізійных жанраў» (Шоу в системе телевизионных жанров). Соответственно, он не согласуется с заданной заголовком интенциональной направленностью статьи (выявмение места шоу в системе телевизионных жанров).

Семантико-прагматический Аиссонанс - погрешность, которая проявмяется в причинно-следственной аргументации. В каузальном обосновании закономерным явмяется дистрибутивный характер использования аргументативных вербализаторов, подчинение их семантических свойств прагматическим (соответственно, положительная оценка слеАствий маркируется лексемами типа способствовать, содействовать, помогать, благоприятствовать и т.п., отрицательная - лексемами преплтствовать, тормозить, затруднять и Ар.). В случае употребления языковых единиц, наделенных «позитивной семантикой», А^я репрезентации негативных 
слеАствий возникает семантико-прагматическая рассогласованность. Такая погрешность чаще наблюдается в русскоязычном Аискурсе (преимущественно в статьях по социологии и психологии): «ИсслеАуются факторы, способствующие воспроизводству и распространению коррупционной практики в современном белорусском обществе» (СА2: 138); «...сейчас в нашем обществе в большей мере востребованы психологические знания, нежели психологическая культура. Это созАает благоприятную почву Аля всевозможного манипулирования мюдьми» (НПЖ1: 17); ОАнако зАесь открывается и перспектива маргинализации научного знания (СА6: 36); «Структурная деформация семьи все-таки крайне нежелательна. Она

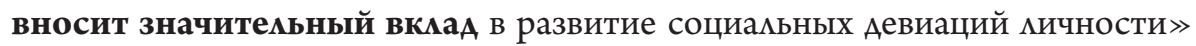
(НПЖ3: 41).

Аналогичные примеры зафиксированы в разнопрофильных текстах на белорусском языке: «Такім чынам, распаўсюджванне апазіцыйнага настрою сярод молаАзі можа стаць значным фактарам у намаганнях апазіцыі Аэстабікізаваць сітуацыю ў рэспубліцы. Разам з тым наяўнасць бюракратычных падыходаў улаА да вырашэння шматлікіх праблем ... садзейнічае Аалейшаму распаўсюАжванню радыкальна-апазіцыйнага настрою сярод значнай часткі моладзі» (Таким образом, распространение оппозиционного настроения среди молодежи может стать значительным фактором в усилиях оппозиции Аестабилизировать ситуацию в республике. Вместе с тем наличие бюрократических подходов властей к решению многих проблем... способствует Аальнейшему распространению радикально-оппозиционного настроения среАи значительной части молодежи) (БА: 121); «Аля сучаснага гледача неігравы фільм з'яуцяецца сінонімам усяго сумнага і стомнага, чаму паспрыяла зАранцвелая клішыраваная форма многіх карцін» (Аля современного зрителя неигровой фильм является синонимом всего скучного и утомительного, чему поспособствовала одеревеневшая клишированная форма многих картин) (ВНАНБ1: 70); «Камічны эффект Аасягаецца пры Аапамозе парушэння максім Грайса» (Комический эффект Аостигается с помощью нарушения максим Грайса) (БА: 141).

Во всех этих аргументирующих рассужАениях негативная оценка слеАствий Аиссонирует с их «позитивным» вербальным преАставлением (позитивная семантика вербализаторов подтверждается словарными толкованиями: Способствовать - 1. Оказывать помощь, содействовать. 2. Быть причиной, помогать возникновению, развитию чего-н. (Ожегов 1990: 756); Благоприятствовать - Способствовать, помогая в чем-н. (Ожегов 1990: 55). ЗАравый смысл в Аанном случае представляется надежным основанием Аля утвержАения: помогать плохому, негативному противоестественно.) Заданная аргументативной схемой когнитивная установка на позитивное слеАствие не оправдывается, что искажает восприятие аргументации.

Ошибки, совершаемые аргументатором на вербально-концептуальном уровне, ощущаются реципиентом как Авижение с препятствиями: понимание аргументации требует напряжения - Аополнительных 
интемлектуальных, эмоциональных и временных затрат, что не способствует эффективности коммуникации.

\section{Заключение}

Выбор языковых среАств, вербализующих аргументацию, входит в зону персонамьной ответственности ученого. Учитывая, что письменный Аискурс характеризуется продуманностью и подготовленностью, а научная статья - продукт Алительной аналитической работы исследователя, погрешности, связанные с неадекватной вербализацией научного обоснования, трудно оправдать. Их профилактика - формирование аргументативной компетенции, а также внимательное и ответственное отношение гуманитариев к презентации результатов научного поиска.

В этом плане преАставляется уместным апемлировать к мнению специалиста по эпистемологии Н.С. Автономовой. Размышияя о философском языке, она замечает: «...Сейчас, наверное, труднее, чем когАа-либо раньше, быть умным, но мегче им казаться: нет не только заданной системы связей межАу понятиями, нет и языка как системы, есть отдельные словечки, которые стало модно объеАинять в цоскутные одеяла» (Автономова 1999: 17). Эти мысли, высказанные Авадцать мет назаА, сегодня не только не потеряли актуальности, но умножили ее многократно. Не менее важен вывоА исследовательницы об ответственности чценов научного сообщества за свои слова и одновременно ответственности «переА словом и понятием» (Там же).

Злободневным явмяется еще одно высказывание Н.С. Автономовой: «научиться читать мысли много сложнее, чем научиться читать буквы» (Автономова 1999: 22). Развивая эту идею, надо признать, что научиться писать мысли (а значит, создавать смыслы) гораздо сложнее, чем научиться писать слова и преАложения. В этом контексте особую значимость приобретает саморефлексия исслеАователей-гуманитариев как путь к профессиональной илентичности.

Как показал сравнительный анализ, некорректное языковое поведение Аопускается и русско-, и белорусскоязычными авторами. Разиичается мишь частотность тех или иных аргументативных ошибок.

Проведенное исследование подтвердило эффективность конвергентного подхода к изучению аргументативного Аискурса: необходимым усмовием качественного анациза и адекватной оценки научно-гуманитарной аргументации явмяется объединение методов Аингвопрагматики и могики.

Разработанная нормативная концепция, как преАставляется, может послужить методологической базой Аля Аальнейших интеграцьных исслеАований аргументации, а также практическим руководством по формированию аргументативной компетенции. 


\section{Литература}

Автономова, Н.С. (1999). Заметки о фикософском языке: традиции, проблемы, перспективы. Bопросы философии. № 1. С. 13-28.

Брутян, Г.А. (1992). Очерк теории аргументаиии. Ереван: ИзА-во АН Армении. 303 с. Аемьянков, В.3. (1982). Конвенции, правила и стратегии общения (интерпретирующий подхоА к аргументации). Известия АН СССР. Сер. ^ит. и яз. Т. 41. С. 327-337.

Еемерен, Ф.Х. ван, Гроотендорст, Р. (1992). Аргументация, коммуникация и ошибки. Пер. с англ. Санкт-Петербург: «Васильевский остров». 208 с.

Киримлова, И.А. (2015). Сфера науки. В: Хорошал речь: коммект. моногр. Сиротинина, О.Б. и Ар. / поА реА. М.А. Кормилицыной и О.Б. Сиротининой. ИзА. 3-е, стер. Москва: URSS: Аиброком. С. 69-84.

Матвеева, Т.В. (2000). Об ортологии текста. В: Культурно-речевая ситуация в современной России: сб. статей / поА реА. Н.А. Купиной. Екатеринбург: ИзА-во Урах. ун-та. С. 21-29.

Ожегов, С.И. (1990). Словарь русского языка: 70000 слов / поА реА. Н.Ю. Шведовой. 22-е изА., стер. Москва: Рус. яз. 991 с.

Савчук, Т. (2016). Вербализация аргументативных структур в научном гуманитарном Аискурсе. В: Русистика и современность. 18-я Междунар. науч. конф.: сб. науч. работ. Рига: Балтийская международная академия. С. 461-468.

Савчук, Т.Н. (2003). Һогика. В 3 ч. Ч. 1. Имена и высказывания. Минск: ИзА-во МИУ. $45 \mathrm{c}$.

Хазагеров, Г.Г. (2010). Обессмысливание научного дискурса как объективный процесс. Социологический журнал. № 2. С. 5-21.

Чернявская, В.Е. (2011). Нормативное и девиантное в научной коммуникации.

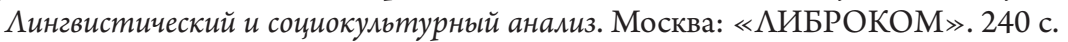

Eemeren, F.H. van, Garssen, B., Krabbe, E. et al. (2014). Argumentation theory. In: Handbook of argumentation theory. Dordrecht [etc.]. Pp. 1-50.

Eemeren, F.H. van (2001). Fallacies. In: Crucial concepts in argumentation theory / ed. by F.H. van Eemeren. Amsterdam: Amsterdam University Press. Pp. 135-164.

Grice, H.P. (1975). Logic and conversation. In: Syntax and Semantics. Vol. 3: Speech Acts. New York: Academic Press. Pp. 41-58.

Leech, G.N. (1983). Principles of pragmatics. London, New York: Longman. 250 p.

\section{Источники примеров}

БА - Казмякоў, У. (2003). Азеткі ці марыянеткі? Беларуская думка. № 8. С. 116-121. БА - Фамічова, Н.В. (2011). Моўныя сродкі выражэння камічнага ў беларускім гумарыстычным фальклоры. Беларускал Аінгвістыка, выпуск 67. С. 144-145.

ВБПАУ1 - Грыцкова, К.В. (2005). Спецыфіка сямейнага ўзаемаАзеяння ў паАлеткавым узросце. Весиі БАПУ. Серыя 1, Педагогіка. Псіхалогія. Філалогія. № 1 (43). С. 40-44.

ВБАПУ 2 - Істамянок, С.С. (2005). Успрыманне Арукаванай рэкламы стуАэнтамі. Весиі БАПУ. Серыя 1, Педагогіка. Псіхалогія. Філалогія. № 2 (44). С. 59-61.

ВБАПУЗ - Петрашкевіч, Н.У. (2006). Роля тыпалагічных Аэтэрмінант у дынаміцы індывідуальна-асобасных уласцівасцей. Весці БАПУ. Серыя 1, Педагогіка. Псіхалогіл. Філалогія. № 1. С. 33-37.

ВБАПУ4 - Мнішкур, К.С. (2005). Псіхалагічная абарона - форма пазітыўнага ўплыву на эмацыянальны стан асобы. Весиі БАПУ. Серыя 1, Педагогіка. Псіхалогія. Філалогія. № 2 (44). C. 46-48. 
ВБАУ1 - Горбач, В.А. (2008). Метанімія як мінгвістычны інструмент дыскурснага аналізу СМІ. Веснік БАУ. Серыл 4, Філалогіл. Журналістыка. Педагогіка. № 2. C. 73-76.

ВБАУ2 - Кузьмінава, А.Ю. (2014). Шоу ў сістэме тэлевізійных жанраў. Веснік БАУ. Серыл 4, Філалогія. Журналістыка. Педагогіка. № 1. С. 84-87.

ВБАУЗ - Шеверинова, О.В. (2015). Номинационные ряды мужских персонажей в антропонимиконе В.П. Астафьева: социопрагматический аспект. Веснік БАУ. Серыя 4, Філалогія. Журналістыка. Педагогіка. № 2. С. 69-73.

ВНАНБ1 - Аашук, В.В. (2005). Паняцце мастацкага стылю ў Аакументальным кіно (на матэрыяле беларускіх неігравых фільмаў). Весиі НАН Беларусі. Серыя гуманітарных навук. № 3. С. 70-76.

ВНАНБ2 - Азімітрук, П.П. (2002). КаАравая сітуацыя ў навуцы Рэспублікі Беларусь. Весиі НАН Беларусі. Серыл гуманітарных навук. № 1. С. 5-13.

ВНАНБ3 - Мыслівец, М.А. (2004). Сацыяльнае самавызначэнне і каштоўнасныя арыентацыі беларускіх студэнтаў. Весијі НАН Беларусі. Серыя гуманітарных навук. № 4. C. 11-16.

ВНАНБ4 - Скараходаў, У.П. (2003). Узаемадзеянне культуры і дзяржавы. Весиі НАН Беларусі. Серыл гуманітарных навук. № 2. С. 74-79.

ВЯ - Кибрик, А.А. (2009). Модус, жанр и Аругие параметры классификации дискурсов. Вопросы языкознания. № 2. С. 3-21.

НИК1 - Калинина, Г.Н. (2012). Паранаука - маргинальное знание или... спор за науку? (в чьи паруса дует ветер века?). Наука. Искусство. Культура, выпуск 1. C. $93-102$.

НИК2 - Сараева, А.П. (2012). Музыкальный фольклор в аспекте его социальнорегумятивного содержания. Наука. Искусство. Культура, выпуск 1. С. 8-17.

НПЖ1 - Аубровина, И.В. (2007). Психологическая культура и образование. Национальный психологический журнал. № 2. С. 16-20.

НПЖ2 - Мамыгина, А.Е. (2010). Темевизионный анонс: информирование ими манипукирование. Национальный психологический журнал. № 2 (4). С. 60-63.

НПЖ3 - Реан, А.А. (2007). Семьи риска. Аети. Общество. Национальный психологический журнал. № 2. С. 40-43.

СА1 - Баханов, А.Г. (2013). Авойственная природа престижного потребления: социологический анализ. Социологический альманах, выпуск 4. С. 251-257.

СА2 - Бубнов, Ю.М. (2011). Коррупция как социальная болезнь. Сочиологический альманах, выпуск 2. С. 138-149.

САЗ - Котмяров, И.В. (2011). Политическая система Бекаруси: теоретическое регулирование и социологическое осмысление. Социологический альманах, выпуск 2. С. 41-53.

СА4 - Синиченко, Р.П. (2013). Хоккей как стиль жизни и зрелище: социологический анализ. Социологический альманах, выпуск 4. С. 469-476.

CA5 - Тарасов, В.С. (2013). Профикактика потребления спиртных напитков и формирование здорового образа жизни. Социологический альманах, выпуск 4. C. 417-425.

СА6 - Федотова, В.Г. (2011). Коммуникация и диалог в науке и за ее предемами. Социологический альманах, выпуск 2. С. 33-40.

ФН1 - Бурвикова, Н.А., Костомаров, В.Г. (2008). Аогоэпистемическая составляющая современного языкового вкуса. Филологические науки. № 2. С. 3-11.

$Ф Н 2$ - Сковородников, А.П., Копнина, Г.А. (2009). О культурно-речевой компетенции студента высшего учебного заведения. Филологические науки. № 3. С. 3-14. 


\section{Semantiski pragmatiskas kḷūdas zinātniskā argumentācijā: krievu un baltkrievu humanitāro zinātṇu teksti}

Rakstā aplūkots krievu un baltkrievu zinātniskais un humanitārais diskurss. Raksta autore sistematizē semantiski pragmatiskas kḷūdas, kuru pamatā ir neadekvāts valodas lìdzekḷu izmantojums un interpretācijas principa neievērošana. Autore raksturo tādus deviācijas veidus kā semantiskas un kategoriju deformācijas, neskaidras references, semantiski pragmatiska disonanse u. c., atklājot šo kḷūdu rašanās mehānismus.

\section{Semantic-Pragmatic Fallacies in Scientific Argumentation (on the material of Russian and Belarusian texts inn humanities)}

The article presents the result of the logical-linguistic analysis of Russian-language and Belarusian-language scientific discourse in humanities. Semantic-pragmatic fallacies, the source of which is the inadequate use of linguistic means because of violation of the principle of interpretability, are systematized. Different kinds of deviations are described such as semantic deformation, categorical shift, semantic failure, referential uncertainty, semantic-pragmatic dissonance etc. The mechanisms of occurrence of these fallacies are identified; their semantic-pragmatic nature is substantiated. 